\title{
THE MANAGEMENT OF LUCERNE IN A CANTERBURY LOW-RAINFALL SHEEP FARMING SYSTEM
}

\author{
B. K. Cameron. \\ Pendarves, Canterbury
}

THE AREA in which we farm (coastal mid-Canterbury) has light alluvial soils (20 to $28 \mathrm{~cm}$ deep) over gravel. The average rainfall of $711 \mathrm{~mm}$ is extremely variable and as evapotranspiration rates are often extremely high in the summer months, there are frequent droughts.

The farm is 270 ha of which 73 ha are spray-irrigated from a $50 \mathrm{~m}^{3} / \mathrm{h}$ bore. There are $101 \mathrm{ha}$ of lucerne on the light nonirrigated soils and a further 28 ha under irrigation. The general farming policy is to combine winter sheep feed production and summer cropping on the irrigated and heavier soils and to have lucerne (as well as grass) for spring, summer and autumn production on the lighter non-irrigated soils. Approximately 3400 ewe equivalents are run, with carrying capacities ranging from about $12 /$ ha in mid-winter, when there is no crop, up to about $21 /$ ha in November on available grazing when about 97 ha of. the farm are in crop.

The objective with lucerne has been to use it as a pasture. In wetter years surplus growth is made into hay but only after grazing requirements have been fully met. This hay is used as a reserve or for special purposes - e.g., feeding as a supplement to hoggets.

After wintering on brassicas and greenfeed, lambing is begun in mid-August on to Tama ryegrass paddocks in the cropping area and approximately 1500 ewes and their lambs set-stocked on these areas. The remaining ewes lamb on to lucerne 3-4 weeks later (in September) and, as soon as possible, are built up into mobs of about 400 ewes and their lambs. These mobs are then rotationally grazed around 6 ha paddocks, staying on each paddock for between 7 and 14 days depending upon the growth that is present.

This mid-September lambing on to lucerne is later than the average for the district and is delayed because lucerne begins growing 3 to 4 weeks later than pasture. With such a system October rainfall is critical. With an average or better rainfall 
the system works well _. the rotation can be slow and the wall of feed in front of the sheep gets bigger. However, when there is a drought in late September and early October the situation is different. Under spring drought conditions, lucerne has a shorter growing period than pasture because it begins spring growth later than pasture and will hold on for only 2 or 3 weeks longer. Therefore, ironically, although lucerne is our most droughtresistant plant, in a very dry spring it can fall short of requirements. On the other hand, advantage can be taken of the ability of pasture to grow during periods of guaranteed moisture - i.e., winter and early spring.

At low stocking rates both lucerne and pasture systems can be made to work in all years. At higher stocking rates alternative techniques must be used in the event of a spring drought. Some of these for lucerne are:

(a) Early weaning. As soon as there are signs of reduced growth weaning is begun at the rate of 400 to 800 lambs per week, as circumstances dictate. It is essential that lambs are weaned while they are still doing well and also while there is good feed to wean them on to. It is better to be too early rather than too late. In some years this means weaning as many as 2500 lambs as young as five weeks of age. These lambs are drenched and rotationally grazed on lucerne in mobs of about 400. The ewes follow to clean tip the roughage. Generally the lambs have about a week on a paddock and the ewes follow on for another week. The lucerne is then spelled for four to six weeks.

(b) Early drafting. A light draft or two of lambs and the sale of works ewes can reduce grazing pressure considerably. The cash loss is often made up later by carrying later drafts to higher weights. This also applies to pasture farming in a drought.

(c) Lucerne oversowing. If there has been sufficient autumn moisture for good establishment, the oversown Tama greenfeed can give substantial winter grazing as well as filling the August gap. If about a third of the area is oversown it should be possible to lamb about 10 days earlier. Although moderately expensive, it makes the system safer. In a dry autumn the oversowing cannot be attempted until there is moisture and this makes it too late to get winter grazing.

(d) Balance of lucerne and pasture. Because the district is coastal it has a mild winter, Subterranean clover regenerates rapidly and gives good winter and early spring production. Current local 
opinion is that the ideal is to have some pasture and some lucerne. Most farmers have enough lucerne for hay and limited lamb grazing while others have up to $50 \%$ of the farm in lucerne and graze it extensively. Lucerne management can fail if the area of lucerne is not sufficiently large to adopt a full rotational grazing system.

(e) Irrigation. With a limited. supply of water, lucerne is probably the best perennial plant to spray-irrigate. Even six weekly irrigations can give large and predictable production increases. With large quantities of water, a permanent all-grass, border-dyke system is probably the most suitable.

All of these techniques are used on our property. They allow flexibility to meet the risk of drought, especially in the critical spring period.

\section{ADVANTAGES OF LUCERNE}

\section{QUALITY}

The leaf and growing tip of lucerne has a high protein content and is highly digestible and palatable. Lambs eat it readily and make fast weight gains. After an initial weaning check, weaned lambs can make weight gains as good as suckled lambs. However, this will only happen if the lucerne is of good quality and the lambs are shifted on to fresh breaks as soon as necessary. Other Legumes - e.g., white clover or subterranean clover - can give the same growth rates but do not have the same carrying capacities or sustained growth in times of moisture stress.

Later in the season this quality is valuable for growing ewe lambs. With the combination of lucerne and some irrigation it has been possible to mate ewe hoggets successfully. This requires sustained and fast growth rates in the summer and autumn. A mob average of $48 \mathrm{~kg}$ liveweight in early April last year enabled us to achieve an $80 \%$ lambing.

Lucerne's rapid recovery with rain and its high quality allows us to flush ewes successfully when conventional pastures under the same conditions do not. Because of its quality, lucerne can give fast weight gains.

\section{PRODUCTION}

Experimental mowing trials in other areas show that lucerne can give up to twice the production of conventional pastures. 
Practical experience in the area would suggest that the difference is not as great as this. One of the main reasons is obviously the practical difficulty of reconciling stock requirements with the optimum lucerne treatment. Also, a mowing type trial would not favour a prostrate plant like subterranean clover and it is possible that we have underestimated pastures in trial work. A further reason for pastures doing well in this district is that many of the so-called light soils are really medium soils.

\section{Drought Resistance}

Once soils have reached wilting point, pastures require considerable rain spread over a period before they will recover. In contrast, lucerne will respond to showers of rain. This feature, plus lucerne's ability to grow for 2 or 3 weeks longer when conditions are getting drier, means that production from November to April is much higher from lucerne than from pasture.

PROBLEMS

\section{GRAZING MANAGEMENT}

Lucerne must be managed on a rotational grazing basis. It must periodically be allowed to reach maturity to build up root reserves. Grazing too soon reduces production. In practice, up to 2 weeks' grazing followed by spelling for as long as possible ( 3 to 6 weeks), is probably the best compromise 'between the plant demand and the stock demands that can be managed in most seasons. This is one of the major difficulties in its utilization. Lucerne has to be grown like a crop before it is utilized and often it is very difficult to keep a series of maturing crops in front of the sheep. In contrast, pasture can be eaten as it is growing and this makes management much easier.

\section{O R M A N C Y}

Lucerne has a dormancy period which extends from May to August. Farm management techniques to overcome this include:

(1) Our system of using the irrigated portion of the farm to provide winter and early spring feed. As well as Tama ryegrass; giant rape, oats and fodder beet have been used,

(2) Using a rotation involving turnips and greenfeed during the course of renewing lucerne stands. This is a cheap and satisfactory method of providing the bulk of the winter feed. 
(3) By actually capitalizing on this dormancy by oversowing winter-growing annual grasses or cereals. This can provide 1100 to $3400 \mathrm{~kg} / \mathrm{ha}$ dry matter over the July/August period, thus filling one of the big gaps in luceme's production. Being annuals, their production tapers off as lucerne growth begins.

(4) By adjusting the lambing date so that peak stock demands coincide with the peak growth period of lucerne - i.e., September/October lambing. In theory, in an average year this is correct but it can put the system under severe strain in a drought year.

(5) Short, fresh growth will withstand frosts and can give useful quality feed early in winter. If not grazed, this winter growth can be carried through and can bring lucerne away in the spring at least one week earlier,

(6) Hay or straw can be. conserved for this period.

(7) The intelligent removal of ewe body weight in midpregnancy can significantly reduce the feed requirements over this period.

\section{Pests AND Diseases}

Since the ban on the use of DDT for grass-grub and porina control in pastures, the resistance of lucerne to these pests has become important. However, at present eelworm, Tasmanian grass-grub, white-fringed weevil and bacterial wilt are all causing concern and anyone of these could reduce the importance. of luceme in this district.

\section{Stock Diseases}

The only two that are predisposed'by feeding lucerne are redgut and pulpy kidney. We have light losses from both diseases in lambs and also from pulpy kidney in ewes. I consider it to be primarily associated with large intakes of young, lush lucerne and therefore ration graze to some degree when lucerne is at this stage of growth.

\section{E S T A B L I S H M E N T}

Provided the well-known rules of correct $\mathrm{pH}$, good seedbed preparation, inoculation of seed, and adequate fertilizer are followed, good establishment should result. Our present method is 
to follow a cleaning winter crop of turnips and undersow the lucerne in a cover crop of barley in early September. In this way we get winter feed, a profitable cash crop in the establishment year of luceme, and are into full luceme production in the second year.

\section{WEED CONTROL}

Barley grass is potentially a very serious weed in luceme and complete eradication should be the aim. Feeding out hay made from weedy pastures or perennial type straw should be avoided on luceme stands. Subterranean clover, white clover, storksbill and annual poa are present in our lucerne stands to varying degrees but are accepted because of their out-of-season production and the variety they give to the diet, resulting in better stock thrift.

\section{IRRIG ATION}

With adequate moisture lucerne has a high summer production and even a small irrigated area can provide fodder at a time when it can be very valuable. Equally, with irrigation, other alternatives open up - e.g., broad red clover can be grown for summer/autumn production or rape for flushing feed.

Our present intention is to retain a balance between lucerne and pasture, in this way getting the best of both systems. By having grass lambing can be sufficiently early to have lambs well advanced before. the onset of a possible drought. By having lucerne we can finish lambs, carry through ewe lambs, and maintain ewes. With both we have the flexibility to handle variations in the climate. 